DOI: $10.15421 / 4219039$

UDC 539.3

\author{
O. V. Pogrebnoy
}

\title{
MODELING OF BIOMECHANICAL SYSTEM ELEMENT STRUCTURE
}

The element structure of a biomechanical system subjected an action of external force factors is studied. The radiocarpal joint of wrist is regarded as biomechanical system. The scaphoid bone is one element of the biomechanical system under investigation. The morphometrical analysis of cuts made in scaphoid frontal plane is fulfilled. The increase of bone tissue density from the cut centre to its periphery is revealed. The significant difference of bone tissue density in proximal and distal parts is determined too. The revealed tendencies allow us to develop the recommendations of construction design for scaphoid osteosynthesis.

Keywords: biomechanical system, modeling, morphometry, radiocarpal joint, scaphoid, spongy bone tissue, fracture.

Introduction. The radiocarpal joint, being one part of human wrist, forms a complex biomechanical system. Performing important functions in human life, this joint is subjected to an action of external forces and an influence of some internal factors that weaken its strength properties. The internal factors consist of different kind deceases, for example, osteoporosis, and time factor.

The biomechanical properties of radiocarpal joint have being studied by various methods. The morphometry methods have wide possibilities for investigation of objects with complex non-homogenous structure [4, 11, $13-15,17]$. The method of computer tomography is very prospective and is widespread in medicine during recent years $[16,19]$. Together with mentioned modern methods the traditional approaches, based on an analysis of specially prepared histological cuts are used often in medical study $[9,12]$.

The time factor, internal property of the biomechanical system, has an essential influence on material weakening that leads to mechanical strength decrease. One of the revealing of such process is a decrease of bone tissue entirety, in our case it is a pore increase in distal radius. The time factor influence on the particularities of wholeness injury of the biomechanical system was studied in [16, 18, 24]. Some problems of recovery of system functionality and values of rehabilitation methods were investigated in [12, 14].

In this paper the study of morphological properties of a biomechanical system element under action of external force factors is presented.

Object of investigation. The radiocarpal joint (articulatio radiocarpea) is considered as biomechanical system, i.e. junction of radius joint depression and three bones of the first row of the wrist: scaphoid (os scaphoideum), lunare (os lunatum), and triquetrum (os triquetrum) [18]. The scaphoid bone is a studied element of the biomechanical system under examination (Fig. 1).

(C) O. V. Pogrebnoy, 2019 


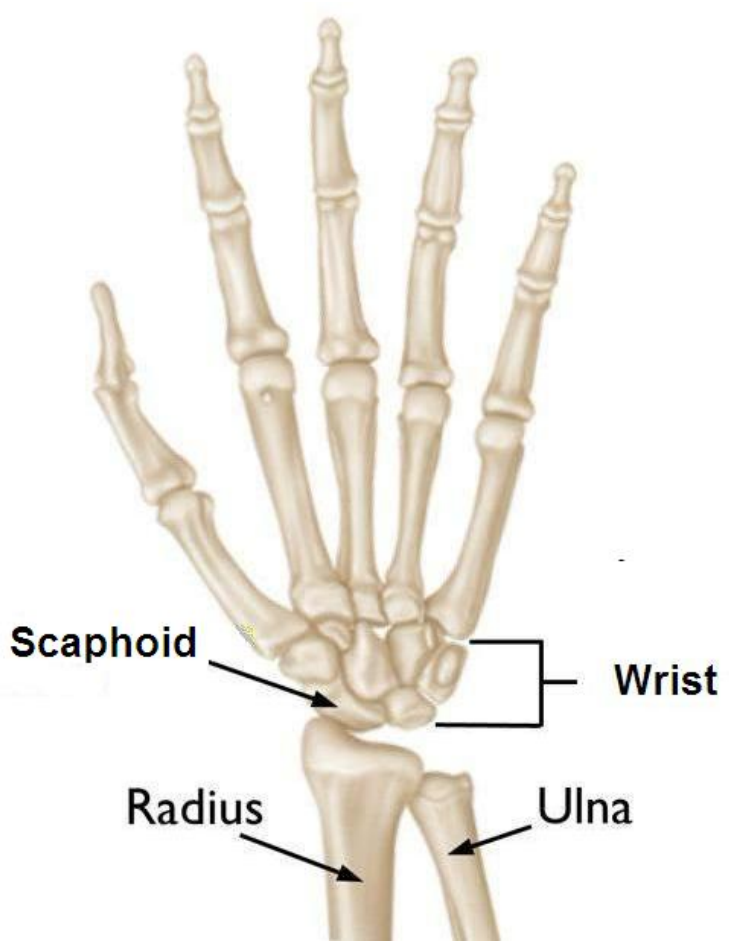

Fig. 1 - Radiocarpal joint and scaphoid location

The scaphoid plays an important role in human wrist functionality. It caries up to $48 \%$ of load, transmitting compressive forces from carpal bones to the radius [7]. The wrist damages make from $25 \%$ to $35 \%$ of hand injuries [3]. The scaphoid traumas have about $2 \%$ in the general amount of bone skeleton fractures [6]. Patients with carpal bone fractures often have damages of scaphoid: $54-88 \%$ cases [1].

The scaphoid occupies a special place in the wrist due to small size of trapezoid bone and is located, as it were, in two rows simultaneously, covering the inter-wrist space. The main feature for wrist biomechanics is the scaphoid oblique location both in sagittal and frontal planes of upper limb related axis in the wrist neutral position. The scaphoid inclination angle with respect to axes of capitate bone and semilunar one is in limits $30-60^{\circ}$ normally. Such special anatomical localization of the scaphoid ensuring the stability to the wrist. Also the scaphoid together with the semilunar, cuneiform and capitate bones forms a special construction that holds tightly a hand both under functional load and without it. In addition to the flexionunflexion movements the scaphoid takes an active part in the radius and ulnar deflections of hand and changes its location during hand displacement from flexion to un flexion, respectively [20]. 
On the base of anatomical principles three main zones are distinguished in scaphoid: 1 - the distal part or tubercle; 2 - the middle part or bone waist; 3 - the proximal part or the bone base. Such a division determinates mainly clinical and radiological methods for diagnosis and treatment of bone fractures [20].

The typical circumstances for the scaphoid fractures are a falling with support on the hand unfolded in wrist, an impact by fist on hard surface or direct impact to the palm [2, 8]. In such cases the direct action on tubercle area leads to fracture and an impact force determines the type and character of damage. The trauma cases are presented schematically in Fig. 2.

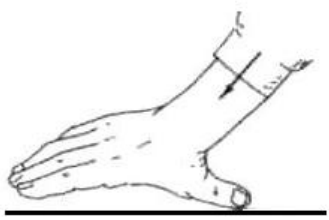

a

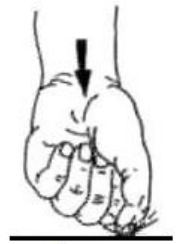

b

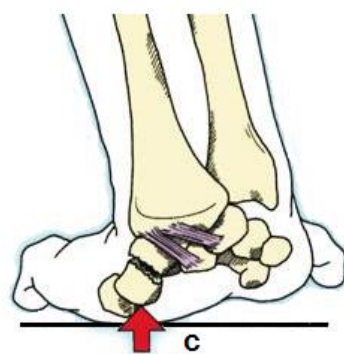

Fig. 2 - Trauma cases with the scaphoid fracture:

a) falling with support on the hand unfolded in wrist;

b) impact by fist on hard surface; c) direct impact on palm

In case of recent damages the fracture types are presented in such a way: first place - distal fracture - $26.2 \%$; second place - proximal fracture $-17.5 \%$; third place - tubercle fracture $-7.5 \%$. For stale fractures: first place - proximal fracture 37\%; second place - distal fracture $7 \%$. The fracture consequences are follows: a significant dysfunction of the wrist joint; a disability; the necessity of medical, social and labor rehabilitation etc. [5]. The main scaphoid fracture types are presented in Fig. 3.

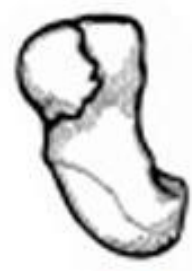

a

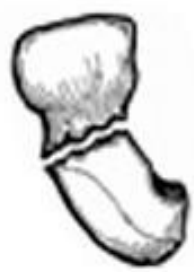

b

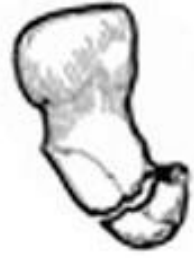

C

Fig. 3 - Main scaphoid fracture types:

a) distal fracture; b) bone waist fracture; c) proximal fracture 
The function peculiarities of the wrist have considerable influence on the scaphoid structure. Unfortunately, papers, devoted to investigations of this problem, are rare. From domestic publications it may be mentioned [10].

Objective of investigation. Modeling of the scaphoid structure as an element of biomechanical system using of morphometrical analysis method in order to provide initial (experimental) data for design of construction elements to fix bone fragments and for improvement of osteosynthesis.

Problem statement. The radiocarpal joint (Fig. 1) regarded as the biomechanical system is under action of external force factors. The structure of scaphoid bone, one element of this system, is studied.

The experimental study was conducted on the scaphoid bone preparation of human wrist. The preparation was decalcified in $7.5 \%$ of water solution of nitric acid for 10 days. The swelling of fibrous structures was eliminated by an additional stay into $96 \%$ of spirits for 24 hours. The preparation length before decalcification was $28 \mathrm{~mm}$. Next the preparation was fortified into liquid and then hardened paraffin. The cuts of thick 12-14 micrometers were made in the frontal plane by the microtome starting from the proximal pole to distal one. The histological cuts were fixed on ground slides and coloured using hematoxylin and eosin in a standard manner. The total quantity of 157 cuts was prepared.

The scaphoid was divided conditionally into three parts: proximal, medial and distal parts. The origin of Cartesian coordinate system $0 x y z$ is placed in the centre of frontal (transverse) cut. The scaphoid bone and coordinate system 0xyz position for frontal cut in the centre of medial part are presented in Fig. 4. The axis $z$ direction coincides with the bone length and perpendicularly to the frontal plane. The axis $x$ is placed in the frontal plane and its positive direction is defined by tubercle of proximal part. The axis $y$ is also placed into the frontal plane and forms with axes $y$ and $z$ the right coordinate system.

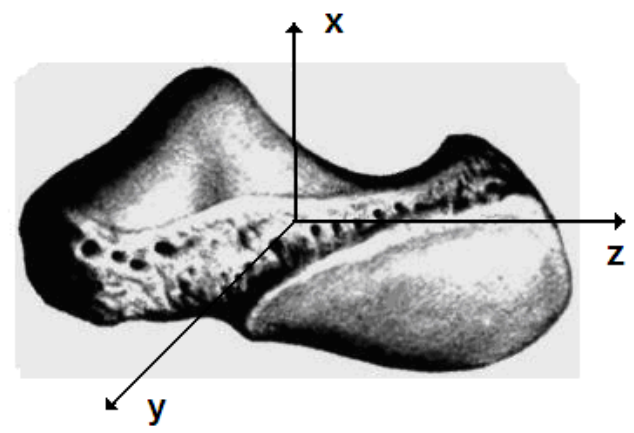

Fig. 4 - Scaphoid bone and position of coordinate system

The cuts were photographed using a LEICA DMLS light microscope at $\times$ 100 magnification and a CANON EOS M42 D30 digital camera. The sponge tissue structure of central and periphery areas was presented on digital 
photos. Then the received digital photographs in the form of data files were transferred to a personal computer. The fragments of cuts in distal and proximal parts are presented in Fig. 5 and Fig. 6. Note, that these images contain the sufficient quantity of different elements of studied structure, so the representative squares are presented.

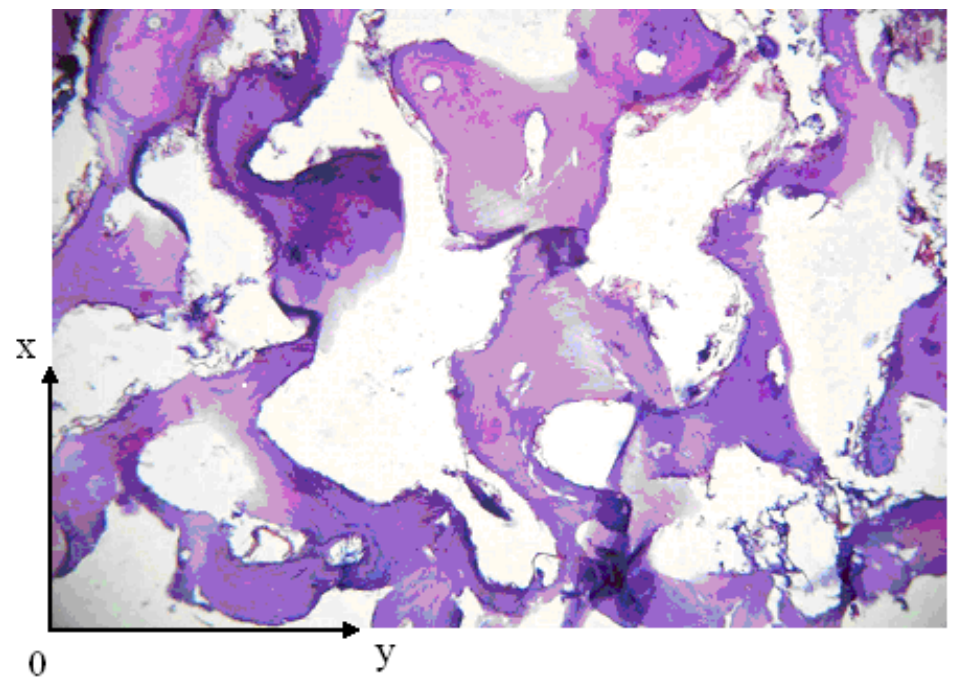

Fig. 5 - Cut fragment in distal part of scaphoid

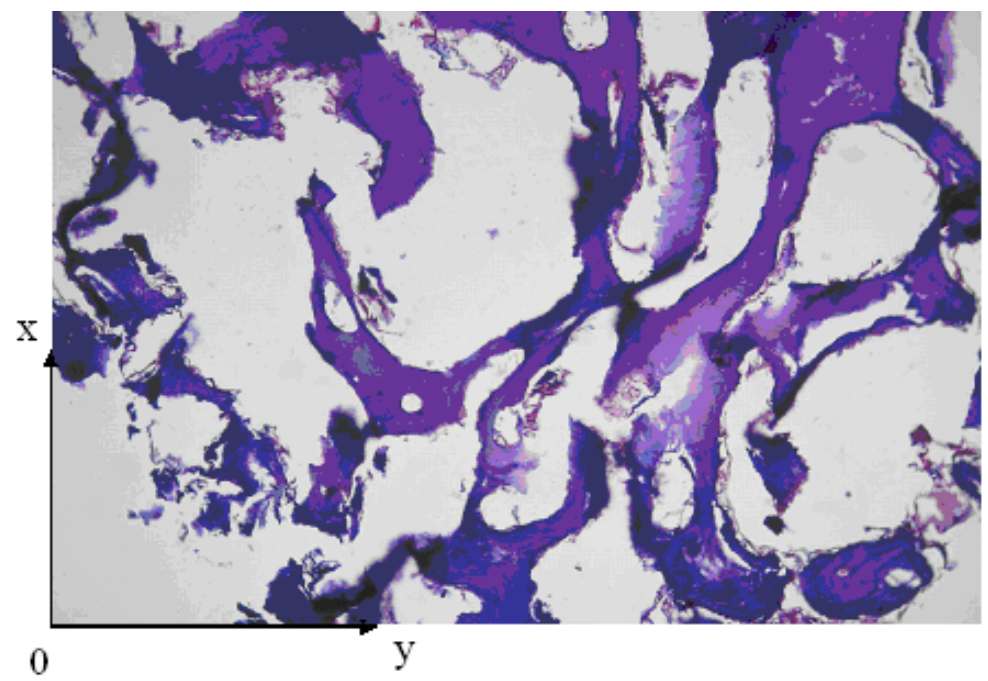

Fig. 6 - Cut fragment in proximal part of scaphoid 
Research results and its analysis. The morphometrical analysis of cut images was fulfilled using a program code, developed in system Delphi [12].

The color images of bone tissue were transformed into monochrome ones. The black color corresponds to the cortical and trabecular (sponge) bone, the white color describes the empty area. To division the bone and the empty area the discrimination level was determined for each image.

The next stage of the morphometrical analysis consists in calculation of number of black and white pixels for both the whole processed image and its fragments. On this basis the relative area occupied by the bone tissue for the whole image and its selected fragments were calculated.

The images in Fig. 5 and Fig. 6 have the sizes $1800 \times 1200$ and $2100 \times 1440$ pixels, respectively. Both images were divided into the fragments of $300 \times 300$ pixels in size, seven fragments in Fig. 6 are of $300 \times 240$ pixels. The relative areas of bone tissue were calculated for each of them.

The results of computer image processing of Fig. 5 and Fig. 6 are presented in Tables 1 and Tables 2, respectively. The relative areas of bone tissue for images in Fig. 5 and Fig. 6 as a whole are 0.550 are 0.436, respectively.

Table 1 - Distribution of relative area of bone tissue

by the cut fragments in distal part of scaphoid

\begin{tabular}{|c|c|c|c|c|c|c|}
\hline Boundaries of & \multicolumn{6}{|c|}{ Boundaries of fragments along axis $y$, pixels } \\
\cline { 2 - 7 } $\begin{array}{c}\text { fragments along } \\
\text { axis } x, \text { pixels }\end{array}$ & $0 \div 300$ & $301 \div 600$ & $601 \div 900$ & $901 \div 1200$ & $1201 \div 1500$ & $1501 \div 1800$ \\
\hline $0 \div 300$ & 0.411 & 0.550 & 0.552 & 0.668 & 0.454 & 0.505 \\
\hline $301 \div 600$ & 0.502 & 0.373 & 0.305 & 0.793 & 0.523 & 0.351 \\
\hline $601 \div 900$ & 0.601 & 0.781 & 0.560 & 0.533 & 0.340 & 0.326 \\
\hline $901 \div 1200$ & 0.912 & 0.622 & 0.618 & 0.705 & 0.572 & 0.633 \\
\hline
\end{tabular}

Table 2 - Distribution of relative area of bone tissue

by the cut fragments in proximal part of scaphoid

\begin{tabular}{|c|c|c|c|c|c|c|c|}
\hline $\begin{array}{c}\text { Bound-aries } \\
\text { of fragments } \\
\text { along axis } x, \\
\text { pixels }\end{array}$ & $0 \div 300$ & $301 \div 600$ & $601 \div 900$ & $901 \div 1200$ & $\begin{array}{c}1201 \div \\
1500\end{array}$ & $\begin{array}{c}1501 \div \\
1800\end{array}$ & $\begin{array}{c}1801 \div \\
2100\end{array}$ \\
\hline $0 \div 300$ & 0.084 & 0.353 & 0.485 & 0.564 & 0.583 & 0.551 & 0.522 \\
\hline $301 \div 600$ & 0.294 & 0.534 & 0.390 & 0.477 & 0.613 & 0.246 & 0.357 \\
\hline $601 \div 900$ & 0.513 & 0.142 & 0.311 & 0.396 & 0.718 & 0.570 & 0.374 \\
\hline $901 \div 1200$ & 0.345 & 0.184 & 0.270 & 0.216 & 0.624 & 0.357 & 0.418 \\
\hline $1201 \div 1440$ & 0.464 & 0.674 & 0.500 & 0.416 & 0.504 & 0.801 & 0.543 \\
\hline
\end{tabular}

Based on the data given in Table. 1 and Table 2, three-dimensional charts are constructed, respectively presented in Fig. 7 and Fig. 8.

The relative area of bone tissue for image fragments was plotted along vertical axis $z$. The position of axes $x$ and $y$ in diagrams corresponds to its position in Fig. 5 and Fig. 6.

In the diagrams in Fig. 9 and Fig. 10 it is visible certain tendency of increasing of relative area with inrcresing of coordinates $x$ and $y$, that is, from 
the cut centre to its periphery. This tendency is more distinctive in the diagram in Fig. 10 and less noticeable in the diagram in Fig. 9. Note that the relative area of bone tissue in distal cut is $11.4 \%$ higher than the proximal cut $(0.550$ versus 0.436$)$.

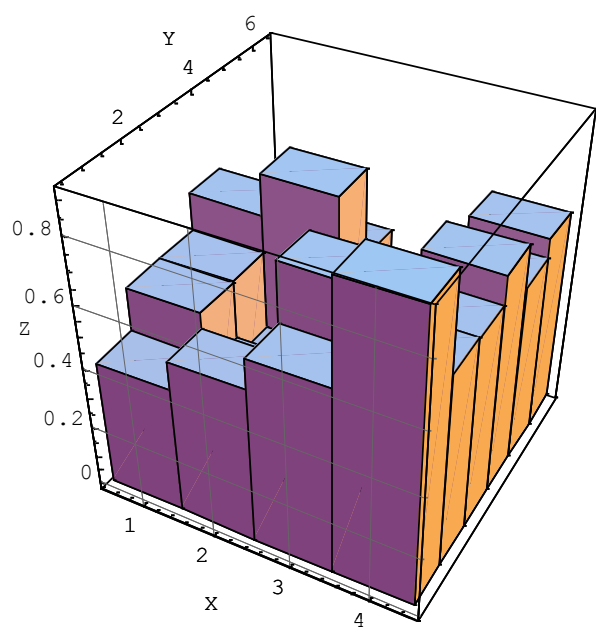

Fig. 7 - Distribution chart of relative bone tissue area by the fragments of cut surface in distal part of scaphoid

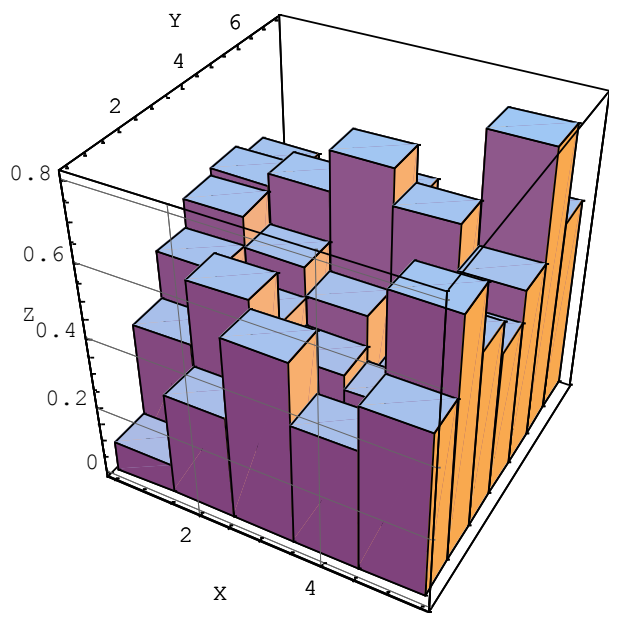

Fig. 8 - Distribution chart of the relative bone area by the fragments of cut surface in proximal part of scaphoid

Note that computer image processing method is, in fact, a variant of Glagolev point-test method [19], used for plane with a regalar system of 
points. At that the relative part of processed image area is calculated, that is, in the case under study, the relative density of bone tissue is found.

The distribution of relative density of bone tissue for parts of cut when changing coordinate $x$ (in pixels) and partial change of coordinate $y$ (from 0 to 300 pixels) in the distal part of scaphoid is presented in Fig. 7.

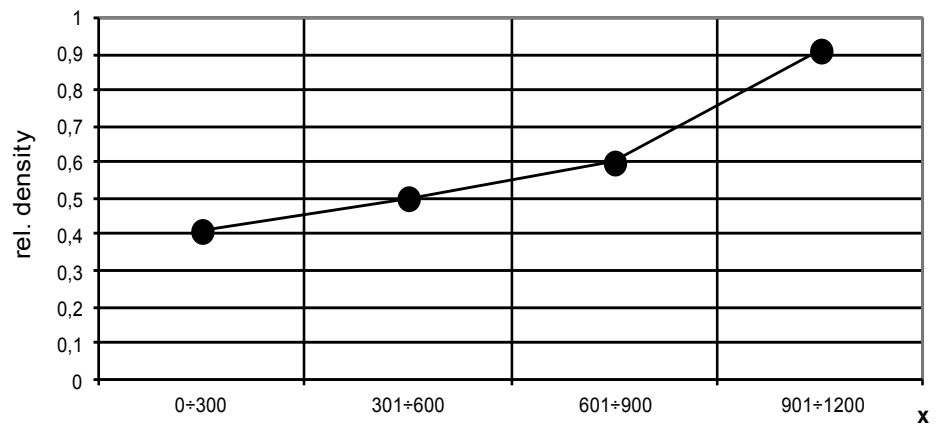

Fig. 9 - Distribution of relative density of bone tissue in distal part of scaphoid

The distribution of relative density of bone tissue for parts of cut when changing coordinate $x$ (in pixels) and partial change of coordinate $y$ (from 0 to 300 pixels) in the distal part of scaphoid is presented in Fig. 10.

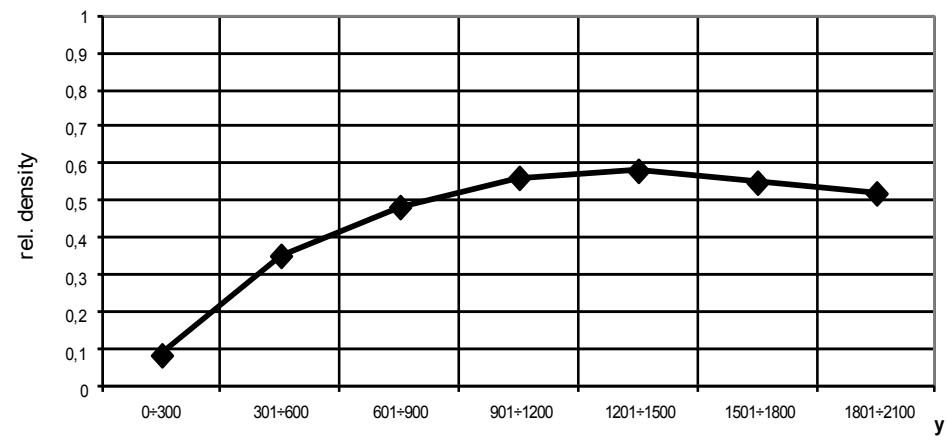

Fig. 10 - Distribution of relative density of bone tissue in proximal part of scaphoid

Conclusions. The morphometrical analysis of tissue structure of scaphoid, the element of biomechanical system under action external forces, is fulfilled. The following results are obtained.

1. The tendency of increase of density bone tissue from the cut centre to its periphery, more distinct to the proximal department, is revealed. 
2. The program code for morphometrical analysis of cut images was developed, which allows obtaining objective characteristics of bone tissue distribution.

3. The revealed structural features of biomechanical system element such as more high bone tissue density in the proximal department compared to distal one form the basis for creation of recommendations for design of osteosynthesis constructions.

\section{REFERENCES}

1. Anisimov V. N., Leontiev N. V., Stroganov A. B. Comparison estimation of fixing efficiency of wrist scaphoid fragments by different constructions of screws // Vesnik traumatology i orthopedics im. N .N. Priorov, 2001. № 3. P. 45-47. (in Russian).

2. Anisimov V. N., Stroganov A. B., Lunin S. A. Surgery of wrist joint damages. Nizhny Novgorod: Vector-Tis, 2003. 100 p. (in Russian).

3. Ashkenazy A. I. Surgery of wrist joint. Moscow: Meditzina, 1990. 352 p. (in Russian).

4. Avtandilov G. G. Medical morphometry. Guide. Moscow: Meditzina. 1990. 384 p. (in Russian).

5. Balagurova G. G., Kikhtenko D. B., Zabanov S. D., Redkov S. N., Alekseev V. N., Divukh $O$. V. The treatment of fractures of navicular and other bones of wrist by the results of trauma service N 1 of state clinical hospital N 3, Irkutsk // Bulletin VSNZ SO RAMN, 2008. № 1 (59), P. 5-7. (in Russian).

6. Cheung G. C. [et al.] X-RAY Diagnosis of Acute Scaphoid Fractures // J. Hand Surgery, 2006. Vol. 31B. No 1. P. 104-109.

7. Genda E., Horii E. Theoretical stress analysis in wrist joint neutral position and functional position // J. Hand Surgery, 2000. Vol. 25B, No 3, P. 292-295.

8. Golubev I. $\mathbf{O}$. Surgery of wrist: carpal instability // Selected problems of plastic surgery, 2001. Vol. 1. No 8. 52 p. (in Russian).

9. Grigorovskii V. V., Strafun S. S., Timoshenko S. V. Histopathology of the wrist tissues and some clinical and morphological correlations in patients with consequences of scaphoid fractures // Genius of orthopedics, 2017. Vol. 23. No 1. P. 30-37. (in Russian) DOI 10.18019/1028-4427-2017-23-1-30-37.

10. Kochetkov A. G., Stroganov A. B. Peculiarities of sponge tissue architectonics of wrist scaphoid // Morphologia, 2002. Vol. 122. No 6. P. 58-61. (in Russian).

11. Naumenko L. Yu., Kirichenko V. Yu., Pavlenko I. D., Kulikov Yu.V., Pogrebnoy O. V. Biomechanical substantiation of reconstructive treatment of scaphoid pseudarthrosis /I Zaporozhsky meditzinsky zhurnal, 2006. Vol. 2. No 5. P. 33-36. (in Russian).

12. Naumenko L. Yu., Pogrebnoy O. V., Kirichenko V. Yu. Morphometrical analyis of the scaphoid bone tissue structure as applied to the osteosynthesis problem // Ukrainsky morfologichy almanakh, 2006. Vol. 4. No 2. P. 86-89. (in Russian).

13. Naumenko L. Yu., Vinnik A. A., Pogrebnoy O. V. Morphometrical characteristic of solid biological tissue in conformity with distal radius metaepiphysis // Trauma, 2010. Vol. 11. No 4. P. 398-404. (in Russian).

14. Naumenko L. Yu., Pogrebnoy O. V., Vinnik A. A. A study of X-ray and morphometrical characteristics of distal radius epimetaphysis by use of computer method // Ukrainsky morfologichny almanakh, 2010. Vol. 8. No 3. P. 93-97. (in Russian).

15. Naumenko L.Yu., Pogrebnoy O.V., Vinnik A.A. Age-specific peculiarities in fractures of the distal radial epimetaphysis // Ortopedia, traumatologia i protezirovanie, 2011. No 4. P. 13-16. (in Russian).

16. Naumenko L. Yu., Vinnik A. A., Cherednichenko N. A. Assessment of the structural characteristics of bone tissue in the distal radius metaepiphysis using the method of computed tomography // Problemi osteologii, 2015. Vol. 18. No 1. P. 46-50. (in Russian). 
17. Pogrebnoy $\boldsymbol{O}$. V. Calculation of the most probable damage place of biomechanical structure on the basis of passive experiment data // Problems of Computational Mechanics and Strength of Structures: Col. of sci. art. Dnipro: Lira, 2017. Vol. 27. P. 137-153. (in Russian).

18. Pogrebnoy $\boldsymbol{O}$. $\boldsymbol{V}$. Modeling of element damage of biomechanical system under action of external force factors // Problems of Computational Mechanics and Strength of Structures: Col. of sci. art. Dnipro: Lira, 2019. Vol. 29. P. 246-259.

19. Saltikov S. A. Stereometrical metallography. Moscow :Metallurgy, 1970. 376 c. (in Russian).

20. Volotovsky A. I., Alikevich Yu. L., Bespalchuk A. P. Modern view on fracture diagnostics of wrist scaphoid // Journal GrGMU, 2011. №-1. P. 69-72. (in Russian).

\title{
УДК 539.3
}

\author{
О. В. Погребной
}

\section{МОДЕЛИРОВАНИЕ СТРУКТУРЫ ЭЛЕМЕНТА БИОМЕХАНИЧЕСКОЙ СИСТЕМЫ}

\begin{abstract}
Исследуется структура элемента биомеханической системы, подвергающейся воздействию внешних силовых факторов. В качестве биомеханической системы выбран лучезапястный сустав кисти человека, а её элементом является ладьевидная кость. Проведен морфометрический анализ фронтальных срезов рассматриваемого элемента. Выявлено возрастание плотности костной ткани от середины срезов к периферии, а также значительное различие В плотности костной ткани проксимального и дистального отделов, что позволяет выработать рекомендации к разработке конструкций для остеосинтеза ладьевидной кости.
\end{abstract}

Ключевые слова: биомеханическая система, моделирование, морфометрия, лучезапястный сустав, ладьевидная кость, спонгиозная костная ткань, перелом.

УДК 539.3

\section{О. В. Погрібний}

\section{МОДЕЛЮВАННЯ СТРУКТУРИ ЕЛЕМЕНТУ БІОМЕХАНІЧНОЇ СИСТЕМИ}

Досліджується структура елементу біомеханічної системи, яка зазнає дії зовнішніх силових факторів. В якості біомеханічної системи розглядається лучезап'ясний суглоб кисті людини, а її елементом обрано човноподібну кістку. Проведено морфометричний аналіз фронтальних зрізів даного елементу. Виявлено зростання щільності кісткової тканини від середини зрізів до периферії, а також значна відмінність в щільності кісткової тканини проксимального і дистальних відділів, що дозволяє виробити рекомендації щодо розробки конструкцій для остеосинтезу човноподібної кістки.

Ключові слова: біомеханічна система, моделювання, морфоометрія, лучезап'ясний суглоб, човноподібна кістка, спонгіозна кісткова тканина, перелом. 